\title{
24. HEAVY MINERAL CONTENT OF SEDIMENTS FROM DEEP SEA DRILL SITES 259-263, EASTERN INDIAN OCEAN
}

\author{
Brian K. McKnight, University of Wisconsin, Oshkosh, Wisconsin
}

\begin{abstract}
Sixty-two samples from five different Leg 27 sites yielded sparse heavy-mineral suites, mostly from fine-grained Mesozoic and Cenozoic unconsolidated sediments. Minerals characteristic of numerous source rock types occur throughout the sedimentary column. Pyroxene is the dominant unstable component in the Mesozoic sediments and hornblende in the Cenozoic sediments. The appearance and disappearance of certain mineral species at different sites throughout deposition of eastern Indian Ocean sediments suggests dispersal patterns may play as important a role in sediment distribution as do changes in provenance. Late Cenozoic sediments from Site 262 in the Timor Trough yield a simple epidote-amphibole suite with a greater total abundance of heavy minerals.
\end{abstract}

\section{INTRODUCTION}

Leg 27 of the Deep Sea Drilling Project drilled at five sites; four sites were located off the west and northwest coasts of Australia and one site in the Timor Trough (Figure 1). Coarse (sand and coarse silt) terrigenous minerals recovered from the sedimentary sequence of these five sites occur in only minor amounts and were not studied in detail during routine shipboard procedures. Dispersal of sand- and silt-size components depends primarily on downslope transport and therefore reflects near-bottom redeposition of continental materials. From the study of these mineral assemblages, important clues may be gained concerning source rock types, degree of weathering of the source area, and regional tectonics. To better characterize these sediments heavy minerals were separated and analyzed.

Samples were disaggregated and wet-sieved. The 63$75 \mu$ fractions were separated by centrifuging with tetrabromoethane, and selected samples were further separated magnetically with a Franz Isodynamic Separator. All grains were mounted and the nonopaque minerals were identified optically with a petrographic microscope.

The heavy-mineral fractions contain abundant nonterrigenous material. Sponge spicules, tests of foraminifera, diatoms, and Radiolaria filled with or partially replaced by pyrite are abundant in the heavy fractions. Much free pyrite is also present as small spherules, irregular blebs, and shapes suggesting foraminifera and diatom outlines. Phosphatic fish fragments, including well-preserved teeth (Plate 1, Figure 9) are locally abundant. Euhedral crystals of barite are present at all five sites and are most abundant at Site 261 .

Reflected light was used to identify the percentage of pyrite in the opaques. Opaques that appeared dark in reflected light were not identified further. Some of these grains may consist of authigenic iron and manganese oxides and do not really represent terrigenous components.

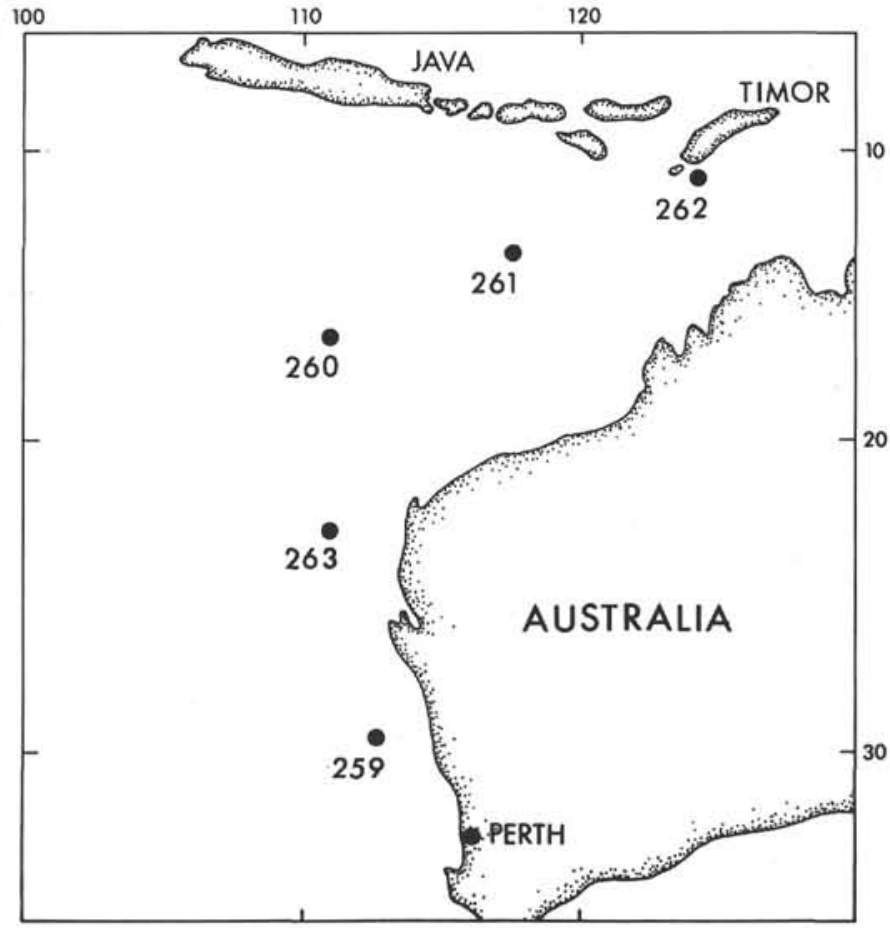

Figure 1. Location of drilling sites occupied on Leg 27, eastern Indian Ocean.

\section{SITE SUMMARIES}

\section{Site 259}

Heavy minerals from Site 259 are sparse and comprise a simple suite. An average of only 27 terrigenous grains per 10-cc sample was recovered from all but two samples. Opaques dominate the heavy fraction; other minerals present in decreasing abundance are zircon, epidote, garnet, hornblende, orthopyroxene, clinopyroxene, tourmaline, sphene, monazite, and apatite.

Zircon, the most abundant nonopaque heavy mineral, typically occurs as sharp euhedra (Plate 1, Figure 3 ) 
although some grains show evidence of rounding (Plate 1, Figures 4 and 5). Colorless crystals predominate; rarely one with a faint bluish tint is present. Epidote occurs as pale- to dark-yellow angular to subangular grains, some of which are composite. Angular, colorless to pale-pink garnet (Plate 1, Figure 6) is present in about one-half of the samples. Hornblende recovered at this site consists of green, angular cleavage fragments. Most are elongate (Plate 1, Figure 7). Prismatic crystals of tourmaline show little evidence of abrasion (Plate 1, Figure 8 ). Strong absorption and buff to dark brownishgreen pleochroism suggest the variety schorlite.

\section{Site $\mathbf{2 6 0}$}

In common with Site 259 , the paucity of heavy minerals characterizes samples from this site. Samples average only 31 heavy mineral grains per 10-cc sample and over $80 \%$ of these are opaques. Epidote dominates the nonopaque fraction with lesser amounts of clinopyroxene, hornblende, zircon, orthopyroxene, garnet, sphene, chlorite, and rutile. Phosphatic fish fragments are very abundant at 53 and 186 meters, and pyrite-filled tests are locally abundant. Nondisaggregated clay lumps that appear to contain 5-15 $\mu$ crystals of hematite, ironstained carbonate (?siderite), pyrite, and opaques occur in some of the separates.

Epidote and hornblende are similar to those at Site 259 whereas the few grains of garnet show more rounding (Plate 2, Figures 2 and 3). Selective solution of pyroxene forming "cockscomb" structures is first seen at 48 meters (Plate 2, Figure 4), but is better developed at 200 meters (Plate 2, Figure 5). This phenomenon occurs on both orthopyroxene and clinopyroxene.

\section{Site $\mathbf{2 6 1}$}

Heavy minerals are almost four times more abundant here than at Sites 259 and 260. This increase is mostly the result of an increase in opaques. The greatest number and variety of nonopaque grains are found at 103 meters; here the separate includes 58 grains of nine different mineral types. Six minerals occur in approximately equal amounts: hornblende, epidote, clinopyroxene, garnet, orthopyroxene, and tourmaline. Traces of apatite and chlorite are also present.

Zircon occurs primarily as well-rounded euhedra; angular, anhedral fragments are much less abundant. One unabraded euhedral grain was found at 310 meters (Plate 2, Figure 6). Angular to subangular garnet ranges in color from colorless to pale pink to pinkish-orange. Except for two crystals, tourmaline (?schorlite) is rounded to well rounded.

Epidote is pale yellow to dark yellowish-green and displays a wide variability in degree of roundness. Green hornblende predominates although six grains of darkbrown hornblende are present at about 55 meters. The brown hornblende occurs as fresh, angular prismatic cleavage fragments. Green hornblende ranges from very angular, almost fibrous cleavage fragments to stubby, rounded grains.

\section{Site 262}

Hornblende (42\%), epidote (30\%), and opaques (17\%) dominate the heavy mineral fraction at Site 262. Minor amounts of pyroxene, actinolite, chlorite, and zircon are present as well as traces of tourmaline, sphene, and garnet.

Hornblende occurs typically as pleochroic dark-green to yellow-green cleavage fragments. Most fragments are stubby with a length to width ratio of $1.5: 1$. The hornblende is typically very angular with delicate edges and points showing no evidence of abrasion. Actinolite, which is pale green to medium green, occurs as long fibrous, slightly pleochroic cleavage fragments with an average length to width ratio of $4: 1$. Epidote displays a variety of forms. Most typical are angular to subangular fragments containing many dust-like and coarser opaque inclusions. These grains show conchoidal fractures on most surfaces. Epidote also occurs as composite grains with individual crystals averaging 10-15 $\mu$ across. Angular, light yellow, limpid fragments with conchoidal fracture occur infrequently. Of special interest are composite grains of epidote and hornblende that occur at 98 meters. Single cleavage flakes and rounded crystalline aggregates of chlorite are rare except in one sample that contains $4 \%$ chlorite. Hypersthene is the dominant orthopyroxene (Plate 2, Figure 7). Sufficient optical data were not available to distinguish the few scattered clinopyroxene grains with certainty.

Nonopaque heavy minerals are abundant in the upper 150 meters but are rare below this level. Most of the terrigenous material is highly angular.

\section{Site 263}

At Site 263 , opaques ( $80 \%$ ), epidote $(7 \%)$, and tourmaline $(3 \%)$ are the most abundant mineral species. Lesser amounts of zircon, hornblende, garnet, pyroxene, and chlorite, as well as traces of actinolite, apatite, sphene, monazite, basaltic hornblende, and kyanite, are present.

Epidote is present in the same forms as at Site 262 except it appears slightly more angular. Tourmaline occurs as well-developed prismatic crystals with numerous inclusions (Plate 2, Figure 8) and as wellrounded, equidimensional grains (Plate 2, Figure 9). Zircon typically forms well-rounded grains that appear to be highly abraded euhedral crystals (Plate 3, Figure 1). A few angular fragments also occur, as do rounded grains that have broken along fractures (Plate 3, Figure 2). Hornblende occurs as short, stubby cleavage fragments often displaying rounding of the corners and irregular ends. Garnet, in contrast to most minerals at this site, is very angular. It occurs as colorless, pinkish, and pinkish-orange fragments with prominent conchoidal fracture (Plate 3, Figure 3). Pyroxene is present in minor amounts in most samples. Etching of the crystals producing "cockscomb" structure is seen in both clinopyroxene (Plate 3, Figure 4) and orthopyroxene. 
The opaque fraction is very abundant in all samples studied from Site 263. The nonopaque fraction is abundant at less than 100 meters but is rare lower in the section. The very well-rounded nature of most zircon and some tourmaline is in sharp contrast with the angularity of all garnet and much tourmaline.

\section{DISCUSSION}

Samples chosen for this study are composed primarily of silt- and clay-size particles with minor amounts of sand. Many are organic oozes. The limited number of nonopaque heavy minerals present in this material seriously limits the significance of the data. Samples larger than $10 \mathrm{cc}$ may be necessary in order to retrieve an adequate number of heavy minerals for statistical studies.

Heavy mineral analyses are usually carried out using sand-size sediments. van Andel (1959) reports that heavy mineral studies of fine-grained rocks are not rewarding. Blatt and Sutherland (1969), however, found fewer altered grains and more trace species in finegrained sediments than in sandstones. They suggested shales and siltstones rather than sandstones should be examined in heavy mineral studies. Scheidegger et al. (1973) found evidence of drastic changes in heavy mineral suites in unconsolidated deep-sea sediments which they attributed to intrastratal solution of minerals in highly porous sand layers. Thus, analyses of relatively impermeable finer-grained sediments may be best for provenance studies. A test for grain-size control performed on three samples showed little difference in mineralogy between 53 and $105 \mu$ fractions. However, the coarser-grained samples produced a greater total number of heavy minerals.

Two major stratigraphic units in the eastern Indian Ocean are recognized by Leg 27 sedimentologists (Robinson et al., this volume). The lowermost unit, referred to as the transparent unit because it lacks internal layering on seismic profiles, is primarily Mesozoic in age. Locally this unit maintains almost uniform thickness regardless of topography. The upper unit, referred to as the layered unit, shows abundant internal reflections on seismic profiles. These layers truncate against topographic highs giving the appearance of ponded sediments. They are Cenozoic in age. These two units are referred to in the following discussion.

Although only a relatively small number of heavy mineral grains were recovered, certain trends can be noted. Figure 2 shows that the abundance of zircon and tourmaline varies greatly in the transparent unit. Because the actual amount of unstable pyroxene plus hornblende does not decrease with an increase in the ultrastable components, the increase in zircon plus tourmaline is most likely the result of a variation in the supply of these components rather than an increase in maturity. Sites 259 and 263, showing high values for the ultrastable components of zircon and tourmaline, lie south of the other sites and may have received sediments through a different dispersal system than Sites 260 and 261. This is not unlikely, as von der Borch (1965) found that the Ord River and Darwin River,

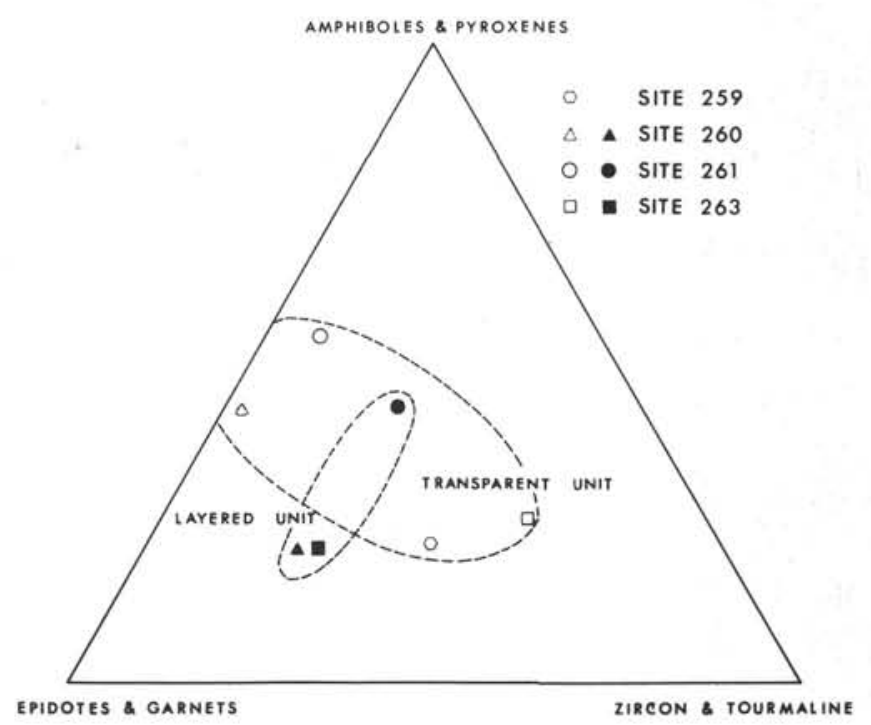

Figure 2. Triangular diagram of heavy mineral assemblages from Sites 259, 260, 261, and 263.

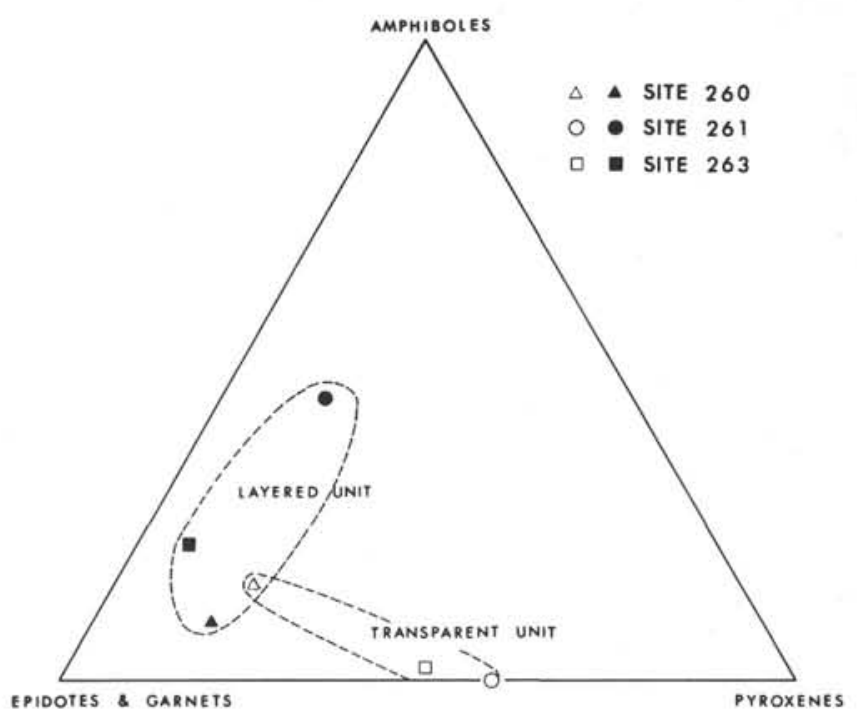

Figure 3. Triangular diagram of heavy mineral assemblages from Sites 260, 261, and 263.

although geographically close to one another, distribute distinctly different heavy mineral suites to the Sahul Shelf of northern Australia. Samples from the Cenozoic layered unit show no difference in the ultrastable components of zircon plus tourmaline at Sites 260,261 , and 263 . The major change is an increase in the unstable components hornblende and pyroxene at Site 261. This could be related to provenance or maturity.

Figure 3 shows pyroxene to be the dominant unstable component of the older transparent sediments at Sites 261 and 263, whereas hornblende is most abundant in the Cenozoic layered unit at the same sites. According to Pettijohn (1957) and Pettijohn et al. (1972), this suggests a change from basic igneous to more acid igneous source rocks. A slight reversal of this trend is noted at Site 260, 
but only 21 grains of pyroxene and amphibole combined were recovered from 12 samples from that site. This may be too small a sample upon which to base an evaluation. Hornblende is present in the lower transparent unit of Sites 259 and 260, but is nearly absent from Sites 261 and 263. It is also present in quantity in the upper layered unit at Sites 261, 262, and 263 but absent at Site 260 . This suggests that a source for hornblende was present throughout deposition of the eastern Indian Ocean sediments but that dispersal of this mineral was not uniform to all sites. Tourmaline is prominent in the layered unit, especially at Site 263. The presence of unrounded euhedra and'well-rounded grains occurring together suggests mixing of primary and reworked sediments. The similarity of the grains, except for the degree of rounding, suggests they may have originated ultimately from the same source. Zircon also shows mixing of well-rounded and fresh euhedra implying a primary and a reworked sedimentary source.

Garnet has a spotty distribution, but it is consistently highly angular. Fresh angular garnet, occurring with angular and well-rounded zircon and tourmaline, supports the idea of a reworked sedimentary source for some of the ultrastable minerals.

Intrastratal dissolution of pyroxene is suggested at Sites 260 and 263. Deep samples from these sites show a somewhat greater degree of etching than do near-surface samples. However, there is no indication that solution has completely removed unstable grains. The finegrained nature of these sediments may impede the free migration of fluids.

Late Cenozoic sediments from the TimorTrough(Site 262) yield a significantly greater number of heavy minerals than do sediments from other Leg 27 sites. This suite is dominated by epidote and amphibole and is very low in the ultrastable components.

\section{SUMMARY}

An initial description of the heavy mineral suites from the sediments of the eastern Indian Ocean shows that relatively few nonopaque heavy mineral grains are present. Conclusions based on this study include:

1) Minerals characteristic of numerous source rock types are found throughout both units;

2) Unstable components are present in both the Mesozoic and Cenozoic sediments;

3) A basic igneous source yielding pyroxenes to Mesozoic sediments gives way to a more acidic source yielding hornblende to Cenozoic sediments;

4) Changes in dispersal patterns through time may be the most important factor in the distribution of heavy mineral suites;

5) Timor Trough sediments yield a simple heavy mineral suite, but the total quantities of heavies is much greater than at the other sites.

\section{REFERENCES}

Blatt, H. and Sutherland, B., 1969. Intrastratal solution and non-opaque heavy minerals in shale: J. Sediment. Petrol., v. 39 , p. $591-600$.

Pettijohn, F. J., 1957. Sedimentary rocks, 2nd Ed.: New York (Harper and Brothers).

Pettijohn, F. J., Potter, P. E., and Siever, R., 1972. Sand and sandstones: New York (Springer-Verlag).

Scheidegger, K. F., Kulm, L. D., and Piper, D. J. W., 1973. Heavy mineralogy of unconsolidated sands in northeastern Pacific sediments: Leg 18, Deep Sea Drilling Project. In Kulm, L. D., von Huene, R., et al., Initial Reports of the Deep Sea Drilling Project, Volume 18: Washington (U.S. Government Printing Office), p. 877 884.

van Andel, Tj. H., 1959. Reflections on the interpretations of heavy mineral analyses: J. Sediment. Petrol., v. 29, p. 153.

von der Borch, C. C., 1965. Distribution of detrital minerals in recent carbonate sediments from the Sahul Shelf, Northern Australia: J. Geol. Soc. Australia, v. 12, p. 333-339. 
HEAVY MINERAL CONTENT OF SEDIMENTS, SITES 259-263

TABLE 1

Mineral Frequencies of Heavy Minerals From Leg 27 Sediments

\begin{tabular}{|c|c|c|c|c|c|c|c|c|c|c|c|c|c|c|c|c|c|}
\hline $\begin{array}{c}\text { Sample } \\
\text { (Interval in } \mathrm{cm} \text { ) }\end{array}$ & 冚 & 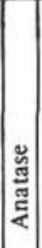 & 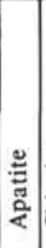 & 冚 & 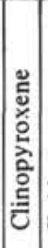 & 을 & ङ્ & 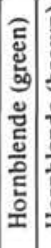 & 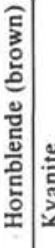 & 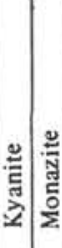 & 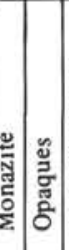 & 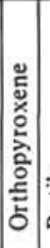 & 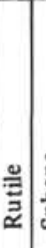 & क् & 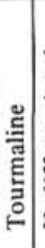 & 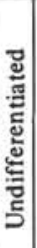 & 总 \\
\hline $259-1-2,142-144$ & & & & & & & 1 & 2 & & & \begin{tabular}{l|l}
1 & 9 \\
\end{tabular} & & & & & & 1 \\
\hline $259-1-6,124-126$ & & & 1 & & & 2 & 1 & & & & 12 & & & & & & 1 \\
\hline $259-4-1,147-149$ & & & & & & 5 & 9 & & & & 568 & 5 & & 1 & 2 & & 11 \\
\hline $259-6-2,126-128$ & & & & & & 1 & & 1 & & & 17 & & & & & & 2 \\
\hline $259-10-6,124-126$ & & & & & & 6 & & 1 & & & 10 & & & & & & \\
\hline $259-13-6,54-56$ & & & & & & 2 & & & & & 10 & & & & & & \\
\hline $259-17-4,1-150$ & & & & & 5 & 5 & 5 & & & & 2285 & 3 & & 1 & 2 & 9 & 17 \\
\hline $259-18-1,133-135$ & & & & & & & & & & & & & & & & & \\
\hline $259-21-2,131-133$ & & & & & & 1 & & & & & 11 & & & & & & \\
\hline $259-23-3,118-120$ & & & & & & 6 & & 3 & & & 29 & & & & & & \begin{tabular}{|l|}
4 \\
\end{tabular} \\
\hline $259-31-1,115-117$ & & & & & 2 & 1 & 1 & 2 & & 1 & \begin{tabular}{|l|l|}
1 & 47 \\
\end{tabular} & & & & & & 4 \\
\hline $260-2-3,3-5$ & & & & & 1 & 1 & & & & & 9 & 3 & & & & & \\
\hline $260-2-3,59-61$ & & & & & & 5 & 1 & & & & 48 & & & 1 & & & 3 \\
\hline $260-3-4,80-82$ & & & & & & & & & & & \begin{tabular}{|l|}
4 \\
\end{tabular} & & & & & & \\
\hline $260-4-5,40-44$ & & & & & & 3 & 2 & & & & 57 & & & & & 1 & 2 \\
\hline $260-5-6,126-128$ & & & & & & 5 & & 1 & 1 & & 13 & & & & & & 1 \\
\hline $260-6-3,94-96$ & & & & 2 & & 3 & & & & & 15 & & 1 & & & & \\
\hline $260-7-2,94-96$ & & & & 2 & 4 & 6 & & & & & 12 & 1 & & 1 & & & \\
\hline $260-7-5,107-111$ & & & & & 2 & 1 & & & & & 16 & & & & & & \\
\hline $260-8-5,100-102$ & & & & & & 1 & & 3 & & & 44 & & & 2 & & & \\
\hline $260-8-6,133-135$ & & & & & & 2 & & 2 & & & 55 & & & & & & \\
\hline $260-10-1,113-115$ & & & & & 1 & & 1 & & & & 20 & & & & & 1 & 1 \\
\hline $260-16-1,124-126$ & & & & & & 5 & & & & & 45 & 2 & & & & & \\
\hline $261-2-2,1-150$ & & & & & 2 & & 1 & & & & 325 & 1 & & & & & \\
\hline $261-3-3,140-142$ & & & & & & & & & 6 & & 13 & 1 & & & & & \\
\hline $261-4-2,92-94$ & & & & 1 & 2 & \begin{tabular}{l|l}
7 & 1 \\
\end{tabular} & \begin{tabular}{l|l}
14 & 1 \\
\end{tabular} & 17 & & & 114 & 1 & & & 9 & & 7 \\
\hline $261-5-1,113-115$ & & & 1 & & & 5 & & & & & 78 & 1 & & & & & \\
\hline $261-6-5,94-96$ & & & 1 & & & 4 & & & & & 277 & & & & + & 1 & \\
\hline $261-8-6,90-92$ & & & & & & & & & & & 6 & & & & & & \\
\hline $261-9-2,90-92$ & & & & & & & 1 & & & & 165 & & & & & 1 & \\
\hline $261-9-3,29-31$ & & & & & & & & & & & 365 & & & & & 4 & \\
\hline $261-19-4,94-98$ & & & & & & & 1 & & & & 35 & & & & & & 1 \\
\hline $261-22-5,90-92$ & & & & & 14 & 3 & & & & & 3 & 7 & & & & & 1 \\
\hline $261-31-2,74-76$ & & & & & & & 1 & & & & 43 & & & & & & 1 \\
\hline $261-31-5,85-87$ & & & & & & & & & & & 5 & & & & & & \\
\hline $262-1-4,99-101$ & & & & 3 & & & & 13 & & & 5 & 1 & & & 1 & & \\
\hline $262-2-4,99-106$ & & & & & & 1 & 1 & 11 & & & 27 & & & & & & \\
\hline $262-3-5,133-135$ & & & & & & 20 & & 15 & & & 2 & & & & & 2 & \\
\hline $262-5-5,49-51$ & & & & & 1 & 4 & & 4 & & & 4 & & & & & & \\
\hline $262-8-3,62-64$ & & & & & 1 & 22 & 12 & 21 & & & 6 & & & & & & 1 \\
\hline $262-9-4,65-67$ & & & & & 1 & 4 & & 3 & & & 6 & & & & & & \\
\hline $262-10-3,42-44$ & & & & & 1 & 13 & & 16 & & & 7 & & & 1 & & & \\
\hline $262-11-5,132-134$ & 2 & & & 4 & 11 & 105 & \begin{tabular}{l|l}
1 & 8 \\
\end{tabular} & 89 & & & 28 & 6 & & & & 3 & \\
\hline $262-13, \mathrm{CC}$ & 6 & & & 4 & 1 & 88 & 11 & 136 & & & 59 & 1 & & & & & 1 \\
\hline $262-14-1,129-131$ & 3 & & & 1 & & 19 & & 22 & & & 10 & & & & & & 1 \\
\hline $262-15-6,99-101$ & & & & & & 2 & & 3 & & & \begin{tabular}{|l|}
8 \\
\end{tabular} & 1 & & & & & 2 \\
\hline $262-16-5,71-73$ & 8 & & & 15 & 5 & 74 & & 208 & 2 & & 84 & 3 & & & & & 1 \\
\hline $262-21-1,49-51$ & & & & & & & & 4 & & & 23 & 1 & & & & & \\
\hline $262-21-4,129-131$ & & & & & & 3 & & 2 & & & 10 & & & & & & \\
\hline $262-28-3,29-31$ & & & & & & & & & & & 3 & & & & & & \\
\hline $262-33-6,146-148$ & & & & & & & & & & & 12 & & & & & & \\
\hline $262.38, C C$ & & & & 1 & & & & 1 & & & 4 & & & & & & \\
\hline $262-44-3,109-111$ & & 2 & & 1 & & 1 & & 9 & & & 8 & & & & \begin{tabular}{|l|}
2 \\
\end{tabular} & & \\
\hline $263-1-3,140-142$ & & & & 1 & 2 & 13 & 5 & 3 & & & 46 & 1 & & & 1 & & 3 \\
\hline $263-2-3,12-14$ & 5 & & \begin{tabular}{|l|}
1 \\
\end{tabular} & 6 & 2 & \begin{tabular}{l|l}
72 & 1 \\
\end{tabular} & 113 & 32 & \begin{tabular}{l|l}
1 & 1 \\
\end{tabular} & \begin{tabular}{l|l}
1 & 1 \\
\end{tabular} & \begin{tabular}{l|l|}
1 & 156 \\
\end{tabular} & 8 & & \begin{tabular}{l|l}
3 & 1 \\
\end{tabular} & 18 & 3 & 18 \\
\hline $263-3-1,60-61$ & 5 & & 1 & 5 & & 525 & 5 & 11 & 1 & 1 & 107 & 2 & & \begin{tabular}{l|l}
3 & 1 \\
\end{tabular} & 13 & & 5 \\
\hline $263-4-1,75-77$ & & & & & & 5 & 1 & & & & 34 & 1 & & & & & \\
\hline $263-8-1,80-82$ & & & & & & 8 & & 1 & & & 208 & 3 & & & & 2 & \\
\hline $263-9-3,123-127$ & & & & & 2 & & & & & & 552 & & & & & & \\
\hline $263-15-3,54-56$ & & & & 4 & 7 & 1 & 1 & & & & 364 & 5 & & 23 & 33 & 5 & 2 \\
\hline $263-17-3,30-40$ & & & & & & 1 & & & & & 282 & & & & & & 1 \\
\hline $263-28-2,100-150$ & & & & 3 & & 1 & & & & & 60 & & & & & & 1 \\
\hline
\end{tabular}




\section{PLATE 1}

All grains are between 63 and $75 \mu$ in diameter as determined by sieve analysis. Plain light.

Figure 1 Euhedral barite crystal. Sample 260-10-1, 113-115 $\mathrm{cm}$.

Figure 2 Euhedral barite crystal. Sample 259-174, 1-150 cm.

Figure 3 Zircon euhedra showing little or no abrasion. Sample 259-4-1, 147-149 cm.

Figure 4 Zircon. Sharp edges have been rounded. Sample 259-4-1, 147-149 cm.

Figure $5 \quad$ Rounded zircon crystal. Sample 259-17-4, 1-150 $\mathrm{cm}$.

Figure 6 Angular garnet typical of those from Site 259. Sample 259-4-1, 147-149 cm.

Figure 7 Prismatic cleavage fragment of hornblende. Sample 259-31-1, 115-117 cm.

Figure $8 \quad$ Tourmaline (?schorlite) crystal. Sample 259-17-4, $1-150 \mathrm{~cm}$.

Figure 9 Fish tooth. Dark central part of tooth displays moderate to strong absorption, low birefringence, wavy and irregular extinction, and an indistinct biaxial positive optic sign. Sample 261-2-2, 1-150 $\mathrm{cm}$. 
PLATE 1
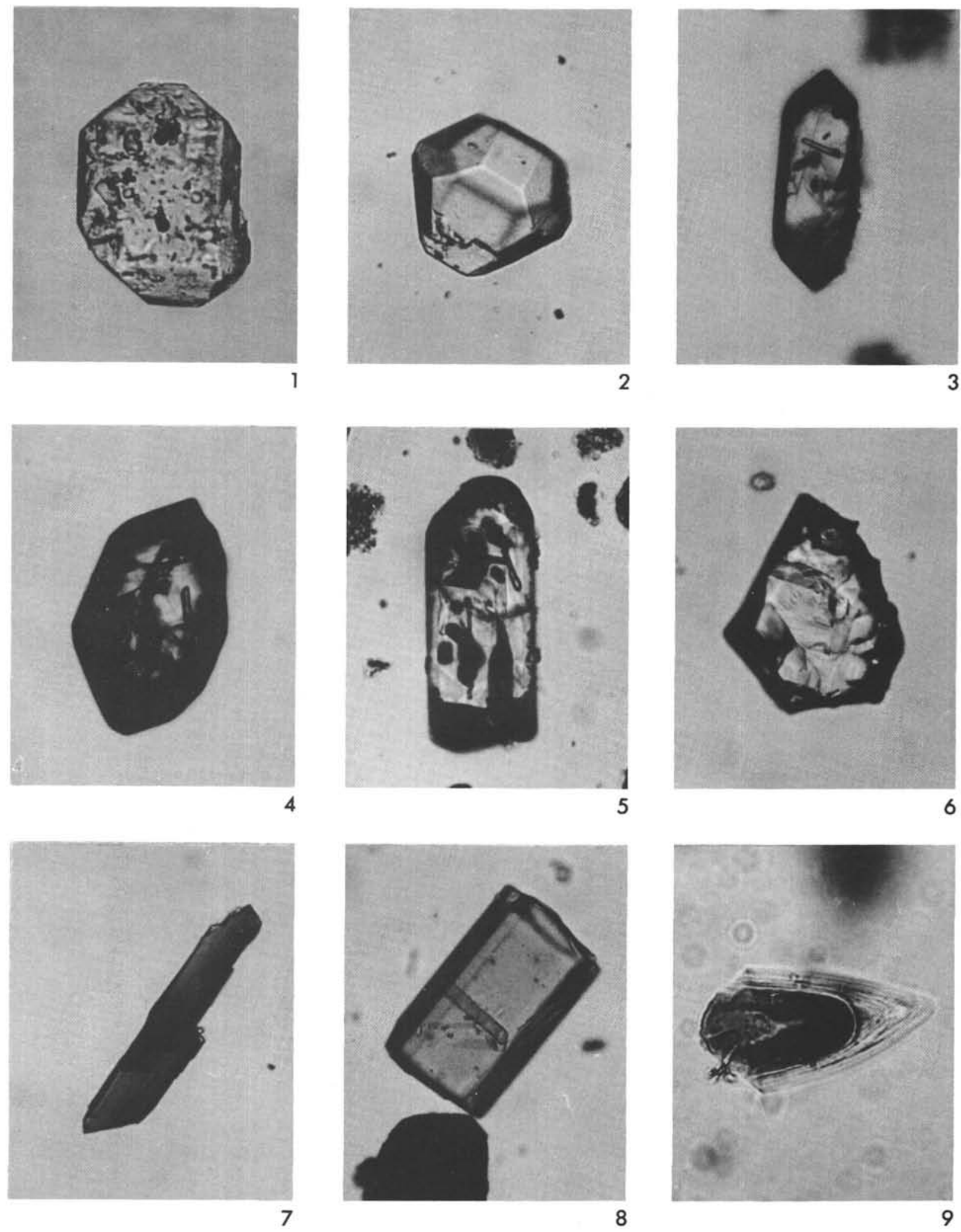


\section{PLATE 2}

All grains are between 63 and $75 \mu$ in diameter as determined by sieve analysis. Plain light.

Figure 1 Dark green hornblende. Sharpest corners are abraded. Sample 260-10-1, 113-115 cm.

Figure 2 Garnet. Greatest degree of rounding of all garnet grains encountered. Sample 260-2-3, 59-61 cm.

Figure 3 Garnet. Sample 260-10-1, 113-115 cm.

Figure 4 Orthopyroxene showing slight etching. Sample 260-2-3, 3-5 cm.

Figure 5 Orthopyroxene showing greater etching than Figure 4. Sample 260-7-3, 50-52 cm.

Figure 6 Angular, euhedral grain of zircon. Sample 261-19$4,94-98 \mathrm{~cm}$.

Figure 7 Hypersthene. Sample 262-11-5, 132-134 cm.

Figure $8 \quad$ Tourmaline (?schorlite) with numerous inclusions. Sample 263-2-3, 12-14 cm.

Figure 9 Well-rounded tourmaline (?schorlite). Sample 263$15-3,54-56 \mathrm{~cm}$. 
PLATE 2
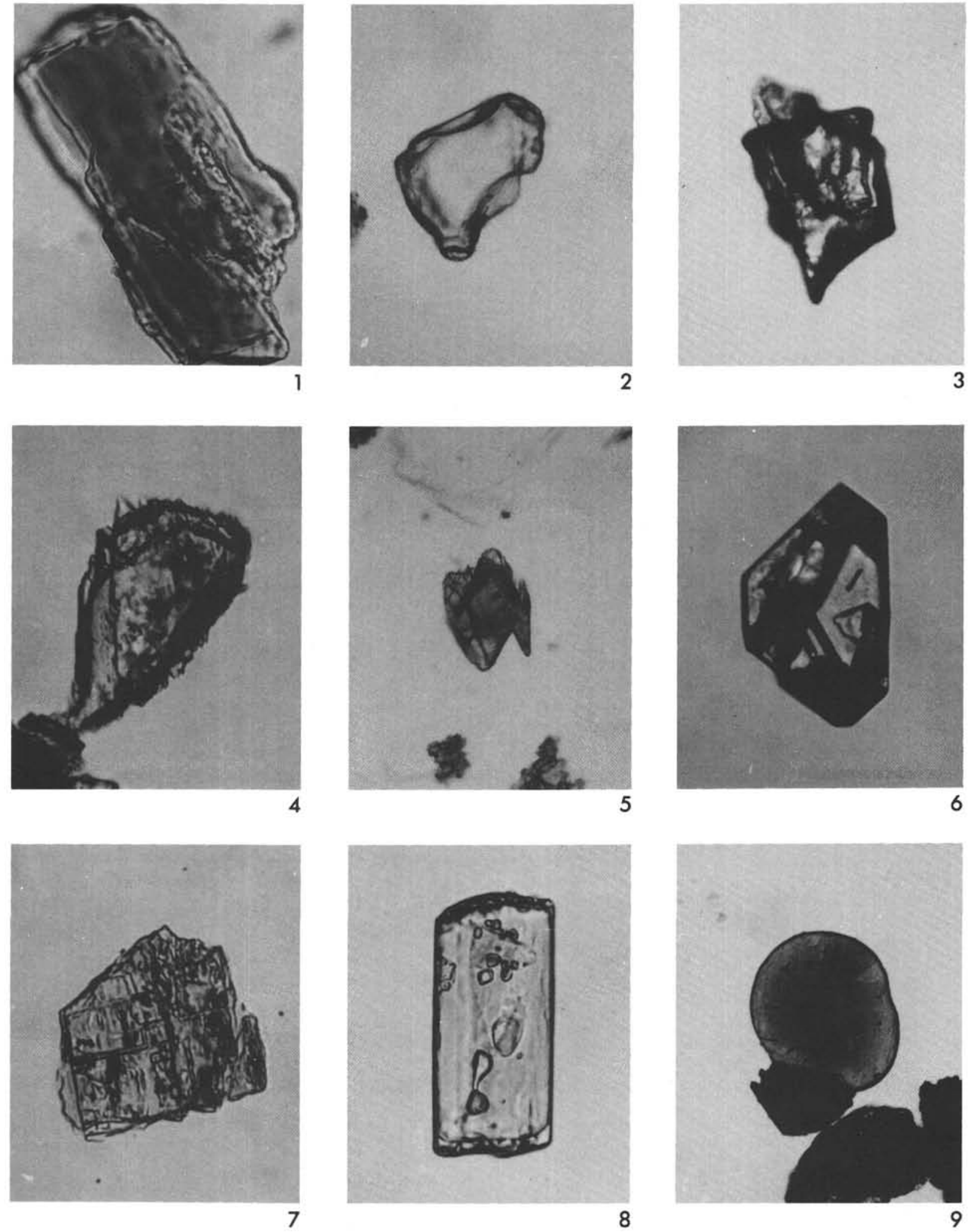


\section{PLATE 3}

All grains are between 63 and $75 \mu$ in diameter as determined by sieve analysis. Plain light.

Figure 1 Rounded zircon euhedra, looking down the $\mathrm{C}$ axis. Sample 263-2-3, 12-14 cm.

Figure 2 Rounded zircon grain broken along one of the prominent fractures. Sample 263-3-1, 60-61 cm.

Figure 3 Angular garnet showing conchoidal fracture. Dark grain is lamprobolite. Sample 263-2-3, 12-14 $\mathrm{cm}$.

Figure 4 Clinopyroxene showing selective etching. Sample 263-2-3, $12-14 \mathrm{~cm}$.

Figure $5 \quad$ Large grain is typical of epidote from Site 263. Sample 263-2-3, 12-14 cm.

Figure 6 Epidote showing evidence of etching. Sample 263$2-3,12-14 \mathrm{~cm}$.

Figure 7 Clinopyroxene with numerous inclusions but showing no signs of etching. Sample 262-38, CC.

Figure $8 \quad$ Zoned crystal of tourmaline (?schorlite). Sample $263-15-3,54-56 \mathrm{~cm}$.

Figure 9 Actinolite grain with numerous inclusions. To the left is foram filled with pyrite. Sample 2632-3, 12$14 \mathrm{~cm}$. 
PLATE 3
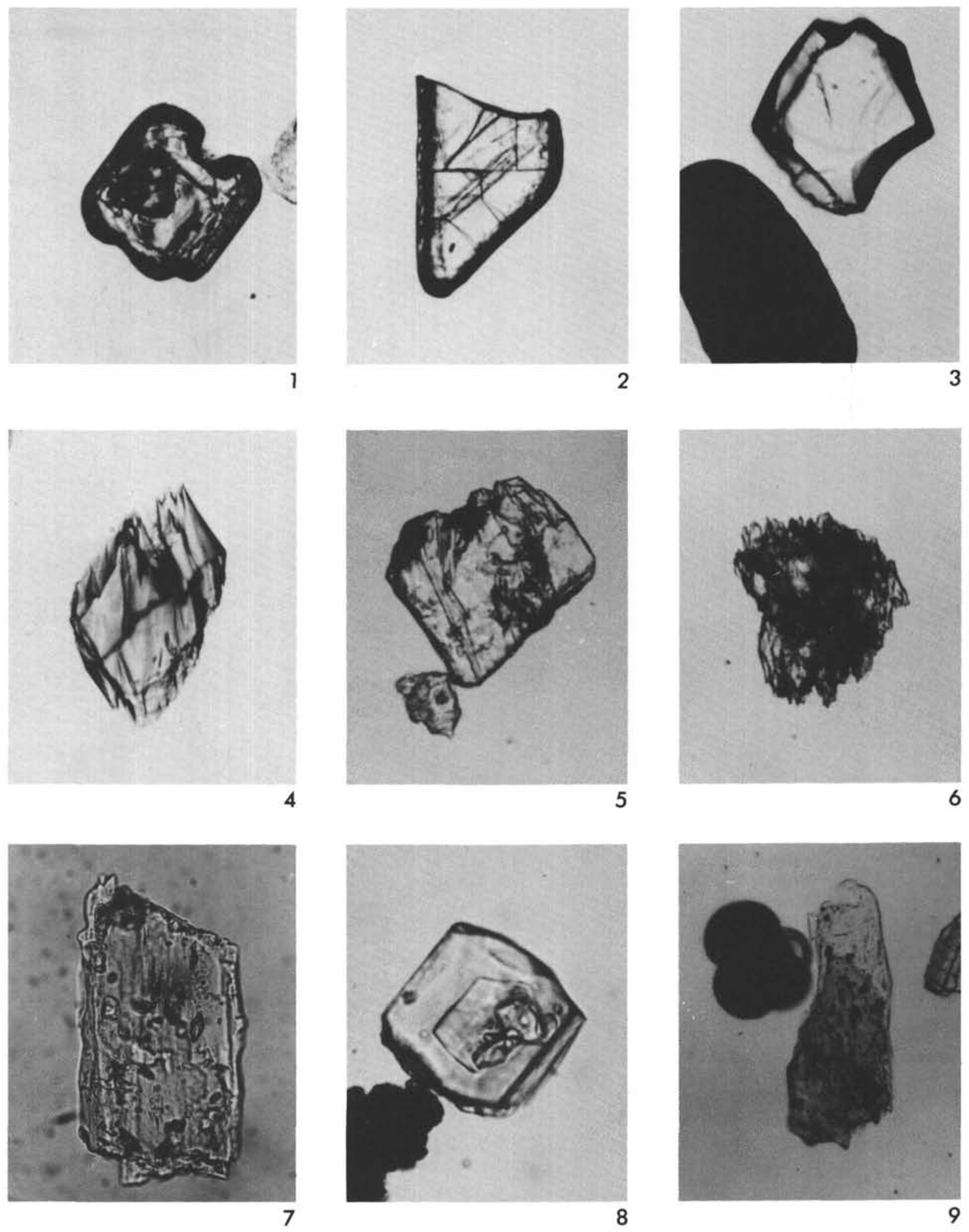